\title{
THE SUMMER MEETING IN EAST LANSING
}

The sixty-fifth Summer Meeting and thirty-ninth Colloquim of the American Mathematical Society was held at the Michigan State University, East Lansing, Michigan, August 30-September 2, 1960. Also meeting at Michigan State University the same week were the Mathematical Association of America, The Society for Industrial and Applied Mathematics, Pi Mu Epsilon, and Mu Alpha Theta. Total attendance at the meetings was approximately 760 including 500 members of the American Mathematical Society.

The 1960 Colloquium Lectures were delivered by Professor S. S. Chern on Geometrical Structures on Manifolds. These were given at 2:00 P.M. Tuesday, August 30, and on 9:00 A.M. the following three days. Professor R. L. Wilder presided at the opening lecture, and at the three subsequent lectures, Professor Chern was introduced by Professors E. H. Spanier, C. B. Allendoerfer and C. C. Hsiung.

By invitation of the Committee to Select Hour Speakers for Annual and Summer Meetings, there were two hour addresses. At 1:30 on September 1, Professor Paul Halmos of the University of Chicago spoke on Recent Progress in Ergodic Theory, and at 1:30 on September 2, Professor P. E. Conner of the University of Virginia spoke on Involutions and Equivariant Maps. Professor Halmos was introduced by Professor J. C. Oxtoby and Professor Conner by Professor George Whitehead.

There were fifteen sessions for contributed papers at various times during the four days of the meeting. Presiding at these were Professors W. T. Kyner, P. E. Conner, A. N. Milgram, Ernst Snapper, E. H. Bareiss, A. J. Lohwater, M. F. Smiley, F. B. Jones, A. D. Lonseth, A. L. Whiteman, J. M. Slye, Joseph Lehner, Bjarni Jönsson, Erik Hemmingsen, and J. Sutherland Frame.

Abstracts of the papers presented in person and by title appear in the Notices of the American Mathematical Society for August and October, 1960, Issues 47 and 48.

The Committee on Arrangements, consisting of W. E. Deskins, Chairman, J. S. Frame, F. Herzog, L. M. Kelly, M. L. Tomber, Director of Publicity, and C. P. Wells, had arranged a coffee hour on Monday Evening, a tea on Tuesday afternoon, and a chicken barbecue on Wednesday evening.

The Council met on Tuesday afternoon, August 30, 1960. 
The Secretary announced the election of the following one hundred twenty-seven persons to ordinary membership in the Society:

Mr. Walter Abramowitz, Grumman Aircraft Engineering Corp., Bethpage, New York; Mr. H. T. Alarcao, University of Nebraska;

Mr. R. H. Anglin, Dan River Mills, Danville, Virginia;

Mr. Morteza Anvari, University of Illinois;

Mr. T. L. Austin, Technical Operations Inc., Fort Monroe, Virginia;

Mr. Nicholas Bakos, United Newspapers Magazine Corp., New York;

Mr. J. F. Barth, Michigan State University;

Mr. D. S. Becker, Sylvania Electric Products Co., Waltham, Mass.;

Mr. A. R. Bednarek, University of Buffalo;

Sister Marion Beiter, Rosary Hill College, Buffalo, N. Y.;

Mr. Harold Bell, Tulane University;

Mr. E. J. Beltrami, Grumman Aircraft Engineering Corp., Bethpage, New York;

Mr. Sergio F. Beltran, National University of Mexico;

Dr. D. R. Bey, Illinois State Normal University;

Mr. P. K. Blackwell, General Electric Co., Syracuse, New York;

Miss Anneliese E. M. Bode, University of Saskatchewan;

Mr. L. M. Bostick, CONVAIR, Fort Worth, Texas;

Mr. Lee Brogan, University of Denver;

Mr. W. F. Cahill, Goddard Space Flight Center, Silver Spring, Maryland;

Mr. W. P. Cash, Jr., University of Texas;

Dr. Maria M. P. Cecchi, Purdue University;

Mr. F. L. Cleaver, Tulane University;

Dr. R. F. Cogburn, University of California, Berkeley, Calif.;

Mr. Arthur Cohen, International Business Machines Corp., Washington, D. C.;

Professor P. E. Conner, Jr., University of Virginia;

Mr. R. J. Cormier, Bell Telephone Laboratories, Inc., Murray Hill, New Jersey;

Mr. H. H. Crapo, Massachusetts Institute of Technology;

Professor F. B. Crippen, Fordham University;

Mr. H. S. Davis, University of Miami;

Dr. Lura Dean, Land-Air, Inc., Point Mugu, Calif.;

Professor C. N. DeSilva, University of Minnesota;

Professor K. W. Endl, Ohio State University;

Professor G. L. Farre, Georgetown University;

Mr. Gabriel Ferrer, Chapultepec, S.A., Lower California, Mexico;

Dr. Uri Fixman, Yale University;

Miss Eileen G. Flaherty, Salve Regina College;

Mr. Henry Frandsen, University of Illinois;

Mr. P. O. Frederickson, Applied Physics Laboratory, Silver Spring, Md.;

Mr. R. M. Gillette, University of Utah;

Dr. Maxwell C. Gilliland, Beckman Instruments, Los Angeles, California;

Mr. M. B. Gordon, Interscience Publishers, Inc., New York, N. Y.;

Mr. L. DeV. Gould, Virginia State College;

Mr. D. S. Grant, University of Manitoba;

Dr. Martin Greendlinger, New York University;

Mr. S. F. Grisoff, International Business Machines Corp., Poughkeepsie, N. Y.;

Mr. Andrew Gyenes, Service Bureau Corp., New York, N. Y.;

Mr. Jack Hachigian, Indiana University;

Mr. W. L. Hafner, Jr., Argonne National Laboratory, Lemont, Ill.; 
Mr. J. H. Hancock, The Marquardt Corporation, Van Nuys, Calif.;

Mr. R. W. Heath, Women's College, University of North Carolina;

Mr. L. S. Horrilleno, Silliman University, Philippines;

Mr. R. A. Holt, Massachusetts Institute of Technology, Lincoln Laboratory;

Dr. H. C. Howard, University of Wisconsin;

Professor P. N. Hu, Pratt Institute;

Dr. Alexandra B. C. Ionescu Tulcea, Yale University;

Professor W. B. Judd, California State Polytechnic College;

Miss Lucy Kasparian, Sylvania Electric Products, Inc., Needham Heights, Mass.;

Mr. I. J. Katz, Operations Research Inc., Silver Spring, Maryland;

Mr. J. L. Kazdan, Institute of Mathematical Sciences, New York University;

Mr. T. A. Keenan, University of Rochester;

Professor J. B. Keller, Institute of Mathematical Sciences, New York University;

Mr. J. W. Kennelly, Jr., University of Florida;

Mr. E. E. Koos, U. S. Naval Air Development Center, Johnsville, Pennsylvania;

Dr. Martin Kulp, Stuggart N., Herdweg, Germany;

Mr. G. R. Lawrey, Jr., Aero Geo Astro Corp., Alexandria, Virginia;

Mr. G. R. Lawson, General Electric Co., Providence, Rhode Island;

Mr. T. J. Lawton, Sylvania Electric Products, Inc., Needham, Mass.;

Professor Alfred Leitner, Michigan State University;

Mr. J. R. C. Leitzel, Bloomsburg State College;

Dr. Shu-tien Li, Mobile, Alabama;

Mr. H. L. Loeb, System Development Corp., Santa Monica, Calif.;

Mr. E. M. Luks, City College of New York:

Dr. Leslie G. MacCracken, Jr., Lehigh University;

Miss Alice A. Manzi, American Telephone \& Telegraph Co., New York, N. Y.;

Dr. F. J. Marshall, University of Chicago;

Mrs. Katherine L. McDuffie, Stanford University;

Mr. W. F. McGee, University of Toronto;

Mr. Jay Mendelsohn, Grumman Aircraft Engineering Corp., New York, N. Y.;

Mr. P. R. Meyer, Columbia University;

Sister Elizabeth Louise Michaels, Emmanuel College;

Dr. W. F. Miller, Argonne National Laboratory, Lemont, Ill.;

Mr. M. J. Meyerhoff, Eastern Research Group, New York, N. Y.;

Miss Elizabeth N. Monahan, State University of Iowa;

Miss Lilly A. Monheit, University of Chicago;

Mr. James H. Moran, Schulberger Well Surveying Co., Ridgefield, Conn.:

Dr. John A. Morrison, Bell Telephone Labs. Inc., Murray Hill, New Jersey;

Mr. J. A. Moyne, Georgetown University;

Dr. J. I. Nieto, University of Maryland;

Mr. Vance D. Norum, Space Technology Labs., Los Angeles, Calif.;

Miss Rose M. O'Connor, University of Connecticut;

Mr. R. K. Otnes, Douglas Aircraft Co., Santa Monica, Calif.;

Dr. C. E. Pearson, Arthur D. Little, Inc., Cambridge, Mass.;

Mr. J. M. Peek, Ohio State University;

Mr. R. E. Peinado, University of Nebraska;

Dr. R. L. Peskin, Princeton University;

Mr. T. J. Powers, Rensselaer Polytechnic Institute;

Mr. William D. Powers, Oak Ridge National Lab., Oak Ridge, Tenn.;

Mr. W. M. Rand, Brandeis University; 
Professor P. H. Randolph, Purdue University;

Mr. Sylvester Reese, Autonectics-NAA, Downey, Calif.;

Mr. J. M. Reichson, Raytheon Co., Sudbury, Mass.;

Mr. E. W. Richardson, Jr., Washington, D. C.;

Dr. D. C. Royal, University of Michigan;

Mr. Richard See, National Science Foundation, Washington, D. C.;

Mr. W. E. Sewell, Duke University;

Miss Barbara P. Sheridan, Interscience Publishers, Inc., New York, N. Y.;

Mr. J. R. Singletary, Fishburne Military School, Waynesboro, Virginia;

Professor Morris Skibinsky, Purdue University;

Mr. J. W. Smith, Yale University;

Professor W. L. Smith, University of North Carolina;

Professor Nathaniel R. Stanley, New York University;

Dr. Howard Stein, Brandeis University;

Mr. J. E. Strout, University of Illinois;

Dr. R. J. Talham, Rensselaer Polytechnic Institute;

Mr. Daniel P. Thompson, Massachusetts Institute of Technology;

Mr. F. T. Turner, Western Union Telegraph Co., Water Mill, Long Island, N. Y.;

Mr. Johannes Tuul, Brown University;

Mr. R. T. Tyler, Knoxville, Tennessee;

Mr. G. N. Vassilakis, Bendix Systems Division, Ann Arbor, Mich.;

Dr. G. R. Verma, Fordham University;

Mr. J. A. Voytuk, Carnegie Institute of Technology;

Mr. N. F. Williamson, Jr., Louisiana State University in New Orleans;

Professor J. T. Weaver, University of Saskatchewan;

Miss Minnie L. Webb, Bell Telephone Laboratories, New York, N. Y.;

Mr. S. L. Whitley, Eglin Air Force Base, Florida;

Professor W. C. Willig, San Fernando Valley State College;

Mr. T. E. Wood, Thiokol Chemical Corporation, Danville, New Jersey.

It was reported that sixteen persons had been elected to membership on nomination of institutional members as indicated:

New Mexico State University: Dr. A. B. Gray.

Princeton University: Mr. P. A. Griffiths.

University of Southern California: Mr. Y. W. Chao, Mr. H. S. Hayashi.

University of Virginia: Mr. M. P. Jones, Mr. D. W. Weaver, III.

Washington University: Mr. F. M. Cholewinski, Mr. J. R. Davis, Mrs. Lee S. Gerber, Mr. J. R. Hattemer, Mr. H. H. Hughes, Mr. Sam Lachterman, Mr. L. A. Machtinger, Mr. P. R. Montgomery, Mr. J. B. Riles, Mr. E. H. Schiek.

The Secretary announced that the following had been admitted to the Society in accordance with reciprocity agreements with various mathematical organizations:

Australian Mathematical Society: Mr. J. A. Lambert, Professor A. F. Pillow, Mr. P. Sprent.

Dansk Matematisk Forening: Mr. E. G. Poulsen.

Deutsche Mathematiker-Vereiningung: Professor Dr. Martin Barner, Dr. V. H. Baumann, Dr. Heinz J. Konig, Professor Konrad Jacobs.

Mathematical Society of Japan: Mr. Nakaaki Arisaka, Mr. Shigeharu Harada, Pro- 
fessor Nagayoshi Iwahori, Mr. Hiroshi Morimoto, Mr. Hideki Ozeki, Mr. Mitsuo Sugiura, Mr. Seizi Takizawa, Mr. H. Sakata, Mr. Yanjiro Okubo, Mr. Masahiro Sugawara.

Indian Mathematical Society: Mr. M. R. Parameswaran, Mr. K. M. Rao, Dr. S. K. Srinivasan, Dr. Y. D. Wadhwa.

Sociêté Mathématique de France: Professor J. O. M. Camargo. Svenska Mathematikersamfundet: Mr. K. Gote Nordlander.

It was reported that Professor Richard D. Mayer represented the Society at the inauguration of Donald Ezzell Walker as President of Idaho State College; Professor James W. Beach represented the Society at the inauguration of John A. Howard as President of Rockford College; and Professor G. C. Evans represented the Society at the centenary celebration for Volterra by Accademia National dei Lincei.

The following committee appointments of the president were reported:

To the Organizing Committee for Summer Institutes for a three year period beginning July 1, 1960: E. E. Moise, A. Erdelyi; and Marshall Hall to be chairman, 1960-61; Committee to Celebrate the 75th Anniversary of the American Mathematical Society: Richard Brauer, R. L. Wilder and G. T. Whyburn; to continue as representative of the American Mathematical Society on the United States National Committee on Theoretical and Applied Mechanics for the four year term beginning January 1, 1961: William Prager.

The Secretary reported that the following have accepted invitations to deliver hour addresses before the Society: P. E. Conner, Summer Meeting, 1960, at East Lansing, Michigan; Shreeram Abhyankar, October, 1960, Holy Cross University; H. L. Royden, November, 1960, California Institute of Technology; Harold N. Shapiro, February, 1961, New York City; Hans Zassenhaus, April, 1961, Stanford University; Daniel M. Kan, April, 1961, New York City, New York; Jacob Wolfowitz, April, 1961, New York City. C. N. Yang has accepted an invitation to give the Josiah Willard Gibbs lecture in January, 1962.

A business meeting of the Society was held at 10:15 A.M. on Wednesday, August 31, 1960, in Anthony Hall Auditorium. P. R. Halmos presided. The Secretary reported briefly on the affairs of the Society.

The following amendments to the by-laws were adopted:

The first sentence of Article II, Section 3, was amended to read as follows:

The Board of Trustees shall have the power to appoint such 
assistants and agents as may be necessary or convenient to facilitate the conduct of the affairs of the Society, and to fix the terms and conditions of their employment.

and Article VI, Sections 2 and 3 to read as follows:

Section 2: The Executive Director shall be appointed by the Board of Trustees with the consent of the Council. The terms and conditions of his employment shall be fixed by the Board of Trustees.

Section 3: The Executive Director shall work under the immediate direction of a committee consisting of the President, the Secretary, and the Treasurer, of which the President shall be chairman ex-officio. The Executive Director shall attend meetings of the Board of Trustees, of the Council, and of the Executive Committee, but he shall not be a member of any of these bodies.

A resolution of thanks and appreciation to the Local Committee on Arrangements and others who assisted with the meeting was presented by Professor W. T. Martin and unanimously passed by the meeting.

J. W. T. Youngs, Associate Secretary J. W. GREEN, Secretary 